\title{
The 2017 General Election in Scotland: a Return to Multi-party Politics?
}

Les Elections législatives de 2017 en Ecosse : retour vers un système

multipartite?

\section{Fiona Simpkins}

\section{CpenEdition}

\section{Journals}

Electronic version

URL: http://journals.openedition.org/rfcb/1903

DOI: $10.4000 /$ rfcb. 1903

ISSN: 2429-4373

Publisher

CRECIB - Centre de recherche et d'études en civilisation britannique

Electronic reference

Fiona Simpkins, «The 2017 General Election in Scotland: a Return to Multi-party Politics? », Revue

Française de Civilisation Britannique [Online], XXIII-2 | 2018, Online since 14 September 2018,

connection on 19 April 2019. URL : http://journals.openedition.org/rfcb/1903 ; DOI : 10.4000/ rfcb.1903

This text was automatically generated on 19 April 2019

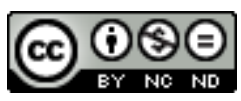

Revue française de civilisation britannique est mis à disposition selon les termes de la licence Creative Commons Attribution - Pas d'Utilisation Commerciale - Pas de Modification 4.0 International. 


\title{
The 2017 General Election in Scotland: a Return to Multi-party Politics?
}

\author{
Les Elections législatives de 2017 en Ecosse : retour vers un système \\ multipartite?
}

Fiona Simpkins

\section{Introduction}

1 Although Scotland was for many years a Labour stronghold, devolution and the creation of a Scottish Parliament in 1999 initially appeared to usher in a multi-party political system. Until then, the Scottish party system, bolstered by the first past the post method, had often been considered as a dominant-party system, as opposed to the UK's two-party system: until the general elections of 2015, the Scottish Labour party had been the first party in Scotland in terms of seats since 1959 and in terms of votes since 1964. It seemed at first that devolution would not erode Labour's domination in Scotland as the party won 56 seats (as opposed to the SNP's 35 seats) in 1999 and 50 seats (compared to the SNP's 27 seats) in 2003. Yet, the fact that Labour was unable to obtain a majority at either one of those elections and had to form coalition governments with the Scottish LiberalDemocrats effectively moved Scotland's new political landscape closer to that of a multiparty system, according to the definition of Giovanni Sartori, ${ }^{1}$ in which several political parties have the capacity to gain control of governmental power, either separately or in a coalition. Indeed, devolution saw the emergence of the Scottish Greens and the Scottish Socialist Party which each won a seat in 1999, and won 7 seats and 6 seats respectively in the Scottish Parliament elections of 2003. Up to six parties were represented in the Scottish Parliament, most of which parties of the left and centre-left, with only the Conservatives standing to the right of the political spectrum. 
2 Yet it soon became evident that devolution served as a political platform for the nationalists who, as Scotland's only mainstream party with no British counterpart, were better able to appeal to a wider electorate keen to protect Scotland's distinctive interests in Scotland's own political arena, as opposed to Westminster where it was generally considered that Scottish MPs did not have a significant voice and where wider British interests were believed to prevail. The 2007 Scottish Parliament election thus returned an SNP minority government for the first time, after which the nationalists were then able to win an overall majority in the 2011 Scottish Parliament election in spite of a semiproportional electoral system explicitly designed to prevent such an outcome. Although the nationalists were unable to translate their growing electoral success into a Yes vote at the 2014 Scottish independence referendum, the latter nevertheless bolstered rather than weakened the pro-independence movement in Scotland. The SNP became the largest party of Scotland in terms of membership and the third largest in the UK, with the number of SNP members surging to more than 120.000. The continuous decline of the Labour party, whose image further suffered during the independence referendum campaign due not only to negative campaigning but also to its shared political platform with the Conservatives, also meant that the SNP faced fewer challengers in Scotland's post-devolution political landscape. The SNP was able to win 56 out of 59 Scottish seats at the 2015 general election and assert its domination of Scottish politics. Scotland had again become a dominant party polity, albeit this time with the nationalists in power.

However, the June 2017 general election appears to have seriously dented the SNP's electoral prospects and has corresponded not only to the unexpected resurgence of Conservatism in Scotland but also to a new surge in Labour votes. Against all odds, the SNP lost 21 seats and 13.1\% of the vote with some safe seats such as those of Alex Salmond or Angus Robertson falling to the hands of the Scottish Conservatives. The Conservatives, on the other hand, increased their share of the vote by $13.7 \%$ and gained 12 seats, all of which from the SNP. Significantly, Scottish Labour also increased its share of the vote by $2.8 \%$ and won six extra seats. This suggests that there has been a disruption in Scottish politics and that the debate which was heretofore polarised on each side of the constitutional issue within a wide centre-left consensus, has become more complex. It appears evident that the Brexit vote following the European referendum of June 2016, which has dominated the British political debate since then, has had a profound impact on Scottish politics. This paper therefore seeks to examine Scotland's return to multiparty politics in light of the twin impact of Brexit and the constitutional issue on the 2017 general election results in Scotland.

\section{From Labour stronghold to SNP territory}

Until the introduction of devolution in 1999, Scotland was widely considered as a Labour stronghold. The Scottish Labour party has deep roots in Scotland's radical history and its origins lay with the party founded by Keir Hardie and Robert Cunningham-Graham in 1888. It was able to draw much of its support in Scotland through the period of mass industrial unrest referred to as Red Clydeside, the anti-war movement and the Glasgow rent strikes which contributed to the development of the labour movement and the radicalisation of the Scottish working class. ${ }^{2}$ This radical past was later refuelled in the 1980s and 1990s with anti-Thatcherism, the anti-poll tax civil disobedience movement and the pro-devolutionist movement which continued to feed the idea of a more 
collectivist, egalitarian and radical Scottish political landscape which the Scottish Labour Party was heretofore able to draw upon to present itself as the party that spoke for Scotland and to establish itself until the mid-2000s as the dominant force in Scottish politics.

However, the Scottish Labour Party has long suffered from structural weaknesses which have become particularly acute under devolution. ${ }^{3}$ Although the Labour Party was initially organised as a conglomerate of affiliated bodies, it became a centralised body after the 1918 party conference when it adopted a national membership scheme and a constitutional framework for a network of constituency and branch parties which operated more as branches of the central office in the regions rather than actual autonomous regional offices. In Scotland, its unitary structure was until recently alleviated by the key role played by its affiliated trade unions in policy-making, as well as candidate selection, leadership recruitment, campaigning and, more importantly, funding. Indeed, it proved to be particularly important in the case of Scottish Labour as the Scottish Trades Union Congress is not a regional branch of the Trades Union Congress but an entirely autonomous body. Yet, with the decline of union members in recent years, the Scottish party has become overwhelmingly dependent on funds allocated by the central party organization. ${ }^{4}$

6 Another weakness of the Scottish Labour Party has been its low membership, which is particularly striking if one is to contrast it with its past political strengths. Labour membership has been consistently lower than anywhere else in Britain since the 1950s: ${ }^{5}$ this suggests that the mobilisation of ground troops for electoral canvassing and campaigning often ran thin. For many years, Scottish Labour may have underestimated the extent to which its electoral strength was due to the first past the post system and overlooked the key electoral functions of local parties whose role in information dissemination, electoral targeting and voter mobilisation have a strong impact on electoral performance. ${ }^{6}$ Scottish Labour's low membership levels therefore constitute a structural weakness which can become especially relevant when it is in a challenging electoral position such as is currently the case, faced with the threat of particularly high mobilisation rates among nationalist members and supporters across Scotland. The SNP is the third political party in the UK today in terms of membership ${ }^{7}$ and has attracted the support of many volunteers, groups and organisations during the independence referendum campaign, which it is able to mobilise ahead of elections to influence the vote.

7 Significantly, devolution also challenged the territorial cohesion of the Labour party. The first test of Scottish Labour's strength in Scotland came with the introduction of the Additional Member System for Scottish Parliament elections: not only did Scottish Labour lose its electoral dominance, but the first two coalition governments of 1999 and 2003 under the Scottish Labour party and the Scottish Liberal Democrats meant that the former had to find agreements with their partners in government and that some of the policies that were considered unpalatable to the Parliamentary Labour Party were effectively introduced in Scotland. ${ }^{8}$ Indeed, it pointed to another inherent weakness of the Scottish Labour party as it had to choose between the cohesive electoral message of the party as a whole and its own electoral priorities in a different political landscape. Unsurprisingly, there have been increasing calls for reforms to make the Scottish party more autonomous and shed its image of a "branch office", 9 many of which having been recently introduced under former leader Kezia Dugdale. ${ }^{10}$ 
8 Although these changes would appear to go in the right direction, Scottish Labour's position on the political spectrum in Scotland's devolved political environment has also proved to be particularly problematic. While its UK counterpart has faced little competition to the left, Scottish Labour has had to contend with several left and centreleft parties, with few differences to be found between Labour and the SNP, for instance, on a wide set of issues. In Scotland, Labour now has to contend with a new left-wing party, RISE, which was formed out of the union of several radical movements active in the independence referendum campaign, as well as the Scottish Greens.

9 Moreover, the core issue of Scotland's constitutional future and the radical character of the pro-independence movement during the referendum debate in Scotland has acted as a substitute to the kind of radicalism that has attracted young activists back to Labour elsewhere in Britain, notably through the student fees protests south of the border or the pro-Corbyn activist movement Momentum. In a nation where there are no student fees, the political awakening of young voters came not with the fees movement but with the independence campaign. ${ }^{11}$ This means that Scottish Labour failed to renew its membership and voter bases as the young radical vote in Scotland now defected to proindependence parties, not least to the SNP whose members below the age of 30 account for $21 \%$ of its total membership.

10 Finally, Scottish Labour's position over the constitutional future of Scotland has plagued the party since the independence referendum of 2014. Scottish Labour's participation in the Better Together No campaign alongside the two coalition government partners at the time will certainly have been damaging in two respects. First because it stood on the same political platform as the Conservatives and second because of the negativity of the Better Together campaign. Although Labour launched its own initiative, United with Labour, in a bid to distance itself from the coalition partners, the campaign was still being led by a senior Labour figure, Alistair Darling. It became an easy target for the SNP, which could present the umbrella campaign as a Conservative-led initiative, which gathered three British rather than Scottish parties and generally defended austerity policies and welfare cuts. It is no wonder then that a nationalist "tsunami"12 swept over the 2015 general election with the SNP winning 56 of the 59 Scottish seats in Westminster, leaving all three unionist parties with a single seat each. The SNP became the dominant force in Scottish politics as it held a majority of seats in both Holyrood and Westminster.

\section{Brexit and the constitutional debate}

11 Indeed, although its outcome was the status quo, the long independence referendum campaign appears to have transformed Scottish politics on a much deeper level than might have been expected. The division between the pro-independence parties led by the SNP within the Yes campaign and the three main unionist parties sharing a single political platform within the Better Together campaign has appeared to survive the referendum and created a new binary system centred along a fracture between unionists and nationalists. The three partners of the Better Together campaign represented both the left and right wings of the political spectrum, yet their association to represent a common position within a single organization during the independence referendum campaign suggests that these traditional left/right divisions were largely made redundant when the main issue at stake was the constitutional future of Scotland. ${ }^{13}$ This was to be well understood by the Scottish Conservative Party in the aftermath of the 2015 
general election when it was presented with evidence at a meeting in October that the constitutional issue could unlock many of the constituency seats it had consistently failed to win during the last twenty years. James Kanagasooriam, a Populus data-analyst, presented his findings to the Scottish Conservative leader, Ruth Davidson, as he explained how he had discovered a pattern that allowed him to devise two new measures to describe and analyse mathematically how people voted. These measures were broadly defined as 'security' - a concept including levels of affluence, education and employment - and 'diversity' - including politics of identity and measurements of how urban an area is. According to these two measures, he discovered a latent line which separated wealthier, more secure and less diverse Conservative voters from less affluent, less secure but more diverse and urban Labour supporters. All voters and places on or close to the line were to be considered as floating voters or marginal constituencies. Interestingly for Ruth Davidson, Kanagasooriam's analysis of the results of the 2014 independence referendum showed that 'temperamentally Conservative voters' overlapped with large numbers of No voters who backed the Union while Labour and the SNP were in a turf war for the same voters due to a demographic overlap. His analysis thus provided evidence that the Scottish Conservatives should run their campaigns as the "Unionist party" rather than attempt to run on bread and butter political issues. ${ }^{14}$

In the run-up to the 2016 Scottish Parliament election therefore, the Scottish Conservative Party based its campaign on a strong unionist message and fully acknowledged the new defining divide in Scottish politics in the aftermath of the referendum. The Scottish Conservatives chose to use the full name of the party (Scottish Conservative and Unionist Party) to appear on their manifesto and all electoral material rather than the shorter version that it habitually used; the main headlines of the manifesto were geared towards marking the party as a party of opposition against the SNP's independence project. ${ }^{15}$ Ruth Davidson conceded that she would not be able to win the election and that the SNP were on course for another victory, before matching Nicola Sturgeon's "job application" in the SNP manifesto with her own application for the job of opposition leader, thereby clearly positioning itself on the other side of Scotland's constitutional divide as the voice of all unionist voters. ${ }^{16}$ The Conservatives thus made their first electoral breakthrough at the May 2016 Scottish Parliament election, after they obtained a total of 31 seats (with $22 \%$ of the constituency vote and 7 constituency seats, and $22.9 \%$ of the regional vote and 24 regional seats), that is 16 more seats than previously held. Although it represented a first important step towards breaking the deadlock in which Scottish Conservatives had been stuck for years, it was far from sufficient to shake the SNP's overall dominance of Scottish politics. Ironically, it was Conservative Prime Minister David Cameron's ill-fated decision to hold a referendum over the United Kingdom's European membership the following month that pulled the rug from under the nationalists' feet.

Indeed, the 2016 Scottish Parliament election manifesto provided for the eventuality of a second independence referendum after a Brexit vote as it stated that a new referendum would be held only "if there is clear and sustained evidence that independence has become the preferred option of a majority of the Scottish people - or if there is a significant and material change in the circumstances that prevailed in 2014, such as Scotland being taken out of the EU against our will". ${ }^{17}$ Although the polls show no such surge in opinion favourable to independence, the discrepancy between the results of the EU referendum in Scotland (with $62 \%$ voting Remain and $38 \%$ voting Leave) and in the rest of Britain does correspond 
to the change of circumstances foreseen by the 2016 manifesto upon which the current SNP government was elected. The party's strong results at the polls in the general election of 2015 and Scottish Parliament election of 2016 certainly gave the Scottish government a clear mandate to do so. It is no wonder then that SNP leader and First Minister Nicola Sturgeon seized the issue of Scotland's membership to the EU in the aftermath of the Brexit vote to meet with EU Council and Parliament leaders to negotiate Scotland's position within the EU and advance the idea of further Scottish autonomy as regards EU membership or access to the Common Market. In December 2016, the Scottish Government also published a White Paper setting out a very different vision of Brexit to that set out by UK Prime Minister Theresa May, defending the idea that Scotland should remain part of the European Single Market and continue to adhere to the EU's provisions on freedom of movement. ${ }^{18}$ Finally, in March 2017, Nicola Sturgeon announced that there would be a second Scottish independence referendum due to the substantial change of circumstances entailed by Brexit. In her speech at Saint Andrews House, the First Minister stressed that the constitutional option which a majority of Scottish voters had voted for in September 2014 no longer existed. Scotland could no longer be part of the UK and the EU at the same time and a new referendum should be set up to ask people in Scotland if they wished to be part of the UK but outside of the European Union or part of an independent Scotland in the EU. Both the constitutional and European issues were therefore presented as entirely wedded and inseparable from each other, with little concern given to the fact that Scots may not weigh the issues of EU membership and independence equally.

The Scottish Social Attitudes Survey of 2016 did ask respondents how likely they were to vote in a future independence referendum (Indyref2) and coupled it with the ways in which both the SNP and the Conservatives in particular linked it to Brexit. In his statistical analysis, McCrone set out the Brexit vote among three variables (libertarianauthoritarian values; Indyref2 and education) and found that those who were most likely to have voted Remain in Scotland (as many as 96\%) were the most highly educated, libertarian and intending Yes voters at a second independence referendum, that is the "core of 'progressive' opinion in Scotland". ${ }^{19}$ It appears that having libertarian rather than authoritarian views gave a major boost to voting Remain, but that education also mattered as among would-be Yes voters there were more Remain voters with either libertarian (96\%) or authoritarian (62\%) views.

Paradoxically, the survey also showed that although people are more likely to vote Yes at a second independence referendum if they are libertarian, voted Remain and have a degree, they are also more likely to vote Yes if they have no educational qualifications and voted Leave. This would provide evidence that the relationship between the way people voted at the European referendum of June 2016 and the way they would vote at a second independence referendum is not as straightforward as it would appear. Indeed, a YouGov poll of January 2017 showed that despite the SNP's advocacy of 'independence in Europe', Brexit significantly divides the nationalist movement as it found that only $65 \%$ of Yes voters who backed Leave said they would back independence again. While some Yes voters may accept that the September 2014 referendum was a 'once in a generation' event, others may want the First Minister to wait longer before holding a second referendum in order to ensure a Yes majority. Finally, some Yes supporters who voted to leave the EU may be opposed to an early ballot as they wish Scotland to be taken out of the institution by the UK government before the country claims its independence. Nearly 
a third of Yes voters at the 2014 referendum and an estimated 36\% of SNP voters voted Leave at the EU referendum, which undermines Nicola Sturgeon's case for a second independence ballot and points to the divisions within the nationalist movement about the merits of EU membership.

Moreover, the Scottish Government's "Scotland's Place in Europe" white paper, published in December 2016, outlines a very different vision of Brexit than the one proposed by the British Government. Throughout this document, the Scottish Government expresses its belief that, short of full EU membership, the "least worst outcome for the UK as a whole" would be to retain full membership of the European Single Market through the European Economic Area (EEA) and to remain in the Customs Union. However, recent polls have shown that contrary to what the EU referendum results in Scotland may suggest, the views expressed by the Scottish Parliament in its white paper are often at odds with those held by a majority of Scots..$^{20}$ While support for free trade does indeed appear universal with as many as $93 \%$ of people expressing the belief that $\mathrm{EU}$ companies should be able to trade freely in Britain while British companies should be able to do the same within the $\mathrm{EU}$, there is widespread support for curbing freedom of movement. Indeed, almost two thirds of Scots (64\%) think that people who wish to move to Britain from the EU should have to apply to do so in the same way as non-EU migrants should have to do, against a mere $22 \%$ opposed to that idea. Opinion therefore is only slightly more liberal than it is across Britain as a whole on this issue where the percentage of people opposed to freedom of movement was $68 \%$. As might be expected, fewer Remain voters in Scotland are opposed to freedom of movement than Leave voters, yet still over half of Remain voters (53\%) are in favour of making EU nationals apply to move to Britain. This explains why there is so little support for freedom of movement north of the border even though Scotland voted so strongly to Remain. These statistics therefore point to the fact that the SNP's stance on Europe and Brexit is at odds with part of the Scottish electorate.

Although it did not focus only on the SNP's independence in Europe objective or on the issue of a second referendum, Nicola Sturgeon's campaign was therefore overshadowed by the European question and divided her electorate. On the other hand, the Scottish Conservatives were able to take full advantage of the fact that their party were negotiating a Brexit deal for the UK, while their leader, whose personal popularity outstrips that of her party, repeatedly stated her preference for a soft Brexit while making opposition to a second referendum the leitmotiv of her campaign. It is therefore unsurprising that the Conservative resurgence in Scotland at the June general election occurred predominantly amongst those who voted No in 2014, wining as much as $44 \%$ of the vote among this group (up 17 points since 2015), well ahead of Labour's 36\% whose more uncertain message on the constitutional issue has failed to make it profitable in terms of vote. Crucially, the Scottish Conservatives picked up $8 \%$ of the vote among those who voted Yes, that is 5\% more than in 2015. This progression among Yes voters is accounted for by the number of Leave voters among them. Indeed, just over one in five (21\%) of those who voted Yes and Leave voted for the Scottish Conservatives in June 2017. Drawing from the soundbite devised by Theresa May after Nicola Sturgeon's shock announcement of a second referendum - 'now is not the time' -, Ruth Davidson therefore clipped the wings of the nationalists as she argued that an anticipated second independence referendum would be unfair to voters as they would not be given sufficient time to make an informed decision. 


\section{Rising from the ashes: Scotland's Conservative phoenix}

The Scottish Conservatives were able to start their campaign with confidence. First, they had little to lose but their single seat in Westminster, in David Mundell's constituency of Dumfriesshire, Clydesdale and Tweedale. This seemed all the more unlikely as the results of the local government elections, which had been held only eight weeks earlier, were particularly encouraging: the party had consolidated its position by obtaining over 100 council seats with a high number of first preference votes for Conservative candidates in target seats for the general election. Moreover, the Scottish Conservatives were ready for battle as they had quietly been selecting and placing candidates in their key target seats over the previous six months. Indeed, the Scottish Conservatives' preparedness for the snap election was immediately visible as they immediately started putting up posters, leafleting and door-to-door canvassing while the other parties were left scrambling to respond to Theresa May's surprise announcement.

Ruth Davidson was also able to remain immune from the increasing chaos of the Conservative campaign south of the border. Theresa May's tightly controlled appearances and uneasiness when meeting ordinary members of the public, her decision not to meet the bereaved inhabitants of Grenfell tower immediately or to take part in head-to-head television debates, did little to dispel the impression that the Prime Minister was disconnected from ordinary people. Besides, many of her key pledges, such as scrapping the 'triple lock' on pensions, means-testing the Winter Fuel Payment, ending free school lunches for all infants and replacing them with free breakfasts, reforming social care funding so that $£ 100.000$ of pensioners' assets were protected (but including their home in the calculation) and holding a free vote in Parliament on fox hunting, were damaging to her campaign. Her U-turn on social care reform (dubbed the "Dementia Tax" in the press) finally demolished the strong and stable image she had attempted to build at the outset of the campaign. In contrast, Ruth Davidson was hailed as a "genuine" leader, ${ }^{21}$ "far from the traditional image of a twinset and pearls Tory", ${ }^{22}$ drawing both strength and popularity from her strong sense of humour, comprehensive education and Protestant middle-class background. With her personal popularity far outstripping that of the Prime Minister, she took full advantage of the prominence of the Scottish broadcast bulletins and print media to become the public face of the campaign in Scotland.

General elections are paradoxical in Scotland insofar as much of the policy agenda matters little because much of it is devolved and part of the Scottish Parliament's remit. The controversies over Theresa May's manifesto thus had little resonance in Scotland where the Scottish Tory leader was able to argue that it did not concern Scotland. Besides, May's most controversial policy on social care was in fact more generous than the existing system in Scotland: while Scotland does provide free social care to the elderly in their own homes, only $£ 26,000$ of pensioners' assets are protected when they go into residential care. It was in none of the main Scottish parties' interests to explain how much more generous the UK Prime Minister's proposal was, and the issue was therefore absent from the Scottish campaign. Moreover, the Scottish Conservatives had already declared themselves opposed to any changes to fox-hunting rules in Scotland and were able to exploit a grey area over which welfare policies were devolved to Scotland to rule out any cuts to winter fuel allowances in their manifesto. 

the constitutional issue. Although she did have seven years of Tory government in Westminster to defend and was virulently attacked over her party's decision to introduce the so-called 'rape clause', ${ }^{23}$ Ruth Davidson relentlessly pursued her winning strategy of 2016 by condemning Nicola Sturgeon's plans for a second independence referendum and presenting her party as a strong opposition party. Launching her general election campaign, she declared:

Across Scotland, we know people are looking for somebody to stand up to the SNP.

So our challenge is this. It's to bring the SNP down to size. To show they can't take

Scotland for granted. ${ }^{24}$

By doing so, she was positioning herself among a majority of Scots and also "subtly inferring that Sturgeon was out of touch, separated from reality and hell-bent on pursuing separation regardless of public opinion". ${ }^{25}$ In fact, all opposition parties in Scotland played upon this idea to attack the nationalists' record in government, suggesting that the SNP was failing to govern due to its obsessive planning for a second referendum. The attacks on the nationalists' handling of the education system or Police Scotland, for instance, paradoxically turned the 2017 general election campaign into a much more Holyrood-oriented political debate. The strategy was not to the taste of the Conservative leadership in London, however, as they felt that Ruth Davidson did not deliver on the 'strong and stable' campaign message that they had set out to develop nationally in order to make of the 2017 general election one that focused on the Prime Minister's persona and which would strengthen her hand to deliver Brexit. Five weeks before polling day, Ruth Davidson was therefore summoned to London by May's Scottishborn campaign manager, Fiona Hill, where she argued her case and pleaded for Populus' involvement.

Returning to Scotland with the funds she needed, the Scottish Conservative leader immediately launched a targeted social media campaign tailored to differentiate the different target voters: SNP Leavers, Lib-Dem 'cultural Tories' and Labour Unionists. ${ }^{26}$ Canvassing data was constantly fed into the Populus model during the campaign while the Conservative campaign poured its funds and efforts into winning the constituencies which appeared on Kanagasooriam's "latent line". The Scottish Conservatives targeted little more than thirteen key seats, many of which were in north-east of Scotland, such as Aberdeen South, West Aberdeenshire and Kincardine, and Banff and Buchan, where the Tories had performed well in 2016 and which were also strong Leave areas in the EU referendum. It was hoped that the Borders area where David Mundell also had a seat would enable the party to perform well, as well as Perthshire, another strong Leave area with historic Conservative support. Finally, the Scottish Conservatives led a bitter fight in the constituencies of Moray and Gordon, respectively held by SNP Westminster leader Angus Robertson and former SNP First Minister Alex Salmond and managed to snatch victory from the jaws of defeat.

\section{Conclusion}

24 In the end, all but one of the seats on Populus' "latent line" fell to the Scottish Conservatives. Yet the strong majority Theresa May had hoped for when she called for a snap election, and which would give her the mandate she needed to pursue her 'vision of Brexit', failed to materialise. The outcome was a reduced Conservative majority and the

Revue Française de Civilisation Britannique, XXIII-2 | 2018 
formation of a minority government after an agreement with the DUP. While the Tories licked their wounds south of the border, Ruth Davidson's Scottish Conservatives won 12 extra seats in Scotland and held on to the one they had previously. It was quite a feat in a country where Conservative MPs had long been wiped out of the map and it was all the more extraordinary because all of the Scottish seats won in 2017 were seized from a heretofore hegemonic SNP. The vote was widely considered as a rebuke of Nicola Sturgeon's calls for a second referendum: although it was unlikely that the SNP would manage to hold on to all of its 54 seats, there was little to suggest that the scale of their defeat would be that formidable. The 2017 general election results halted the SNP's momentum for independence - as the First Minister conceded that she would have to postpone her plans for an early independence referendum - and put an end to the nationalists' domination of Scottish politics, ushering in a new multi-party polity split along an ever deeper constitutional divide.

Fiona Simpkins is a Senior Lecturer in British contemporary history and politics at the Université Lumière of Lyon (Lyon 2). Her main areas of research are devolution, Scottish politics and the constitutional debate in Scotland.

\section{BIBLIOGRAPHY}

Brooks, L., "Jeremy Corbyn 'can help Labour rebuild Scotland”, Guardian, 24th August 2016.

Curtice, J., "Does Scotland Want a Different Kind of Brexit?", NatCen Social Research and SCotCen Social Research, March 2017.

Gordon, T., "Scottish Labour donations collapse in Dugdale's first year as leader", Herald Scotland, $22^{\text {nd }}$ February 2017.

Harvey, O., "Scottish Tory leader Ruth Davidson postpones wedding to fiancée", The Sun, $28^{\text {th }}$ July 2017.

Hassan, G. \& Shaw E., The Strange Death of Labour Scotland (2012), Edinburgh, Edinburgh University Press.

House of Commons, Membership of UK Political Parties, Briefing Paper SN05125, House of Commons Library, 1 May 2018.

Liddle, A., Ruth Davidson and the Resurgence of the Scottish Tories (2018), London: Biteback Publishing Ltd.

McCrone, D., "Explaining Brexit North and South of the Border", Scottish Affairs, 26.4, 2017, 391-410.

MacWhirter, I., Tsunami. Scotland's Democratic Revolution (2015), Glasgow: Freight Books.

"Ruth Davidson: 'We will bring SNP back down to size”, Scotsman, $8^{\text {th }}$ May 2017.

Sartori, G., Parties and Party Systems: A Framework for Analysis (1976), Cambridge: Cambridge University Press. 
Scottish Conservative and Unionist Party, A Strong Opposition. A Stronger Scotland. The Scottish Conservative and Unionist Party Manifesto 2016.

Scottish Government, Scotland's Place in Europe, 20th December 2016.

Scottish National Party, Re-Elect, 2016 Manifesto, April 2016.

Shipman, T., Fall Out. A Year of Political Mayhem (2018), London: William Collins.

Simpkins, F. "The Conflicting Loyalties of the Scottish Labour Party" in Avril, E. \& Beliard Y., Labour United and Divided from the 1830s to the Present (2018), Manchester: Manchester University Press.

Simpkins, F., "The 2016 Scottish Parliament Elections: Unionist Parties and the Constitutional Divide", Revue Française de Civilisation Britannique, XXII-4, 2017.

Spence, B., "The Tories need to learn from Ruth Davidson if they want to stay in power", The Independent, $11^{\text {th }}$ June 2017.

\section{NOTES}

1. Sartori, G., Parties and Party Systems: A Framework for Analysis (1976), Cambridge: Cambridge University Press.

2. Hassan, G. and E. Shaw, The Strange Death of Labour Scotland (2012), Edinburgh: Edinburgh University Press.

3. Simpkins, F. "The Conflicting Loyalties of the Scottish Labour Party" in Avril, E. \& Y. Béliard, Labour United and Divided from the 1830s to the Present (2018), Manchester: Manchester University Press.

4. This has been particularly the case in recent years as the party experienced a sharp drop in donations. A majority of donors contribute to the statewide party rather than its substate branches. In 2015, income was $£ 1.073,108$, of which $£ 592,641$ was donations, and expenditure was $£ 974,931$, leaving a surplus of $£ 98,177$. But in 2016 , despite election years usually boosting donations, income slumped to $£ 400,436$, of which $£ 105,752$ was donations, and expenditure was $£ 504,402$, leaving a deficit of $£ 103,966$. (Herald Scotland, $22^{\text {nd }}$ February 2017)

5. It declined from 19,703 members in 1993 and 30,770 members in 1998 to an all-time low of 13,135 members in 2010 before rebounding to 21,500 members in 2017 due to the rising popularity of Corbyn in Scotland after his successful 2017 general election campaign.

6. Hassan \& Shaw, op. cit. 2012

7. The SNP accounted for 118,200 members in April 2018. House of Commons, Membership of UK Political Parties, Briefing Paper SN05125, House of Commons Library, 1 May 2018. www.parliament.co.uk/commons-library, last access $14^{\text {th }}$ June 2018.

8. This would most famously be the case of the Graduation Endowment and Student Support (Scotland) Act 2001, a compromise reached after the Liberal-Democrats had made the issue of the abolition of tuition fees their main requirement in the talks leading to Scotland's first coalition government agreement and which came as the Labour government in Westminster was reintroducing top-up fees in England and Wales.

9. As she resigned in October 2014, former Scottish Labour Party Johann Lamont accused the Parliamentary Labour Party of treating its Scottish counterpart as a "branch office". 
10. Some changes such as those to the system of leadership elections, for instance, mirrored those brought to the Parliamentary Labour Party, but they were followed by an agreement struck in October 2015 between Kezia Dugdale and Jeremy Corbyn for the further decentralisation of powers to Scottish Labour which would include full authority over all organisational and financial aspects, including the selection of Westminster and European candidates.

11. Brooks, L., "Jeremy Corbyn 'can help Labour rebuild Scotland", Guardian, 24th August 2016.

12. MacWhirter, I., Tsunami. Scotland's Democratic Revolution (2015), Glasgow: Freight Books.

13. Simpkins, F., "The 2016 Scottish Parliament Elections: Unionist Parties and the Constitutional Divide", Revue Française de Civilisation Britannique, XXII-4, 2017.

14. Shipman, T., Fall Out. A Year of Political Mayhem (2018), London: William Collins, p. 384.

15. "Ruth Davidson for a Strong Opposition", "No to a Second Referendum", "Holding the SNP to Account", and "A Scottish Conservative and Unionist Approach". In the foreword, Ruth Davidson once again the acknowledged the distinctiveness of a new Scottish political landscape defined along the unionist/separatist axis: "This is not a normal foreword, not is this a normal manifesto. That's because this isn't a normal election".

16. "As much as I would like to imagine myself First Minister in a few weeks' time, with my new cabinet around me; I know that this is not the job the majority of Scotland's voters have in mind for me on May 5 $5^{\text {th"; }}$ "Instead, I'm applying for another job. Because there is an important vacancy in Scottish public life that I, along with my team, are best placed to fill. And that is the vacancy for a strong opposition".

17. Scottish National Party, Re-Elect, 2016 Manifesto, April 2016.

18. Scottish Government, Scotland's Place in Europe, 20th December 2016.

19. McCrone, D., "Explaining Brexit North and South of the Border", Scottish Affairs, 26.4, 2017, 391-410.

20. Curtice, J., "Does Scotland Want a Different Kind of Brexit?", NatCen Social Research and SCotCen Social Research, March 2017.

21. Spence, B., "The Tories need to learn from Ruth Davidson if they want to stay in power", The Independent, $11^{\text {th }}$ June 2017.

22. Harvey, O., "Scottish Tory leader Ruth Davidson postpones wedding to fiancée", The Sun, $28^{\text {th }}$ July 2017.

23. Changes announced by former Chancellor George Osborne in the Budget in 2015 and brought to the Welfare Reform and Work Act 2016 that came into effect on $6^{\text {th }}$ April 2017 which forced a woman to prove she had been raped in order to claim child tax credits for more than two children. The UK government limited child tax credit to the first two children but exemptions to the changes were announced for those adopting children, involved in kinship care, multiple births or for a child born as a result of "non-consensual conception".

24. "Ruth Davidson: 'We will bring SNP back down to size", Scotsman, $8^{\text {th }}$ May 2017.

25. Liddle, A., Ruth Davidson and the Resurgence of the Scottish Tories (2018), London: Biteback Publishing Ltd, p. 300.

26. Shipman, T., op. cit. 2018, p. 390. 


\section{ABSTRACTS}

Although Scotland had long been a Labour stronghold, devolution soon appeared to have served as a political platform for the nationalists who were able to assert their domination of Scottish politics after they obtained both an overall majority of seats in Holyrood in 2011 and 56 out of 59 Scottish seats at Westminster in 2015. Scotland had become a dominant-party polity and the SNP the third biggest party in Britain. However, the June 2017 general election appears to have seriously dented the SNP's electoral prospects and has corresponded not only to the unexpected resurgence of Conservatism in Scotland but also to a new surge in Labour votes. It appears evident that the Brexit vote following the European referendum of June 2016, which has dominated the British political debate since then, has had a profound impact on Scottish politics. This paper therefore seeks to examine Scotland's return to multi-party politics in light of the twin impact of Brexit and the constitutional issue on the 2017 general election results in Scotland.

Bien que l'Ecosse ait longtemps été un bastion travailliste, la dévolution y servit de tremplin électoral pour les nationalistes en ce qu'ils parvinrent rapidement à dominer entièrement le paysage politique écossais en obtenant une majorité absolue des sièges au Parlement écossais dès 2011 avant de remporter 56 des 59 sièges écossais à Westminster en 2015. L'Ecosse fut alors caractérisée par un système à parti dominant et le SNP devint le troisième parti du Royaume-Uni. Néanmoins, les élections législatives de juin 2017 ébranlèrent la domination électorale des nationalistes écossais en ce qu'elles produisirent non seulement une résurgence inattendue des conservateurs mais aussi une progression du vote travailliste. Le processus du Brexit, suite au référendum de juin 2016 sur l'adhésion du Royaume-Uni à l'Union Européenne, qui a dominé le débat politique depuis lors, semble ainsi avoir profondément transformé les enjeux politiques en Ecosse. Il s'agira dès lors d'analyser le double impact de la question constitutionnelle et du Brexit sur les résultats des élections législatives britanniques de juin 2017 en Ecosse et un retour vers un système politique multipartite.

\section{INDEX}

Mots-clés: Brexit, élections législatives britanniques 2017, politique écossaise, parti conservateur écossais, parti travailliste écossais, SNP, dévolution, référendum sur l'indépendance de l'Ecosse

Keywords: Brexit, general elections 2017, Scottish politics, Scottish Conservative Party, Scottish Labour Party, SNP, devolution, Scottish independence referendum

\section{AUTHOR}

\section{FIONA SIMPKINS}

Senior Lecturer in British contemporary history and politics at the Université Lumière of Lyon (Lyon 2). 